\title{
Optimum Welding Parameters for Friction Stir Welded AA6063 Pipe Butt Joint Using the Taguchi Method
}

\author{
Azman Ismail, Fatin Nur Zulkipli, Mokhtar Awang, Fauziah Ab \\ Rahman, Puteri Zarina Megat Khalid, Bakhtiar Ariff Baharudin
}

Welding parameters for pipe joint friction stir welding (FSW) have been identified based on L-9 orthogonal arrays used in the Taguchi Method. Different welding parameters, such as rotation speed, travel speed and axial force, have been used to produce several quality friction stir welded AA6063 pipe butt joints. The reliability of products obtained in the FSW process can be improved through the identification of the optimum combination of welding parameters. Weld quality was evaluated based on its tensile strength and residual stress profiles. The $\mathrm{S} / \mathrm{N}$ analysis and Analysis of Variance (ANOVA) have been used to determine significant welding parameters that affect weld quality. Maximum tensile strength with acceptable residual stress was obtained at the optimum welding parameters of $1300 \mathrm{rpm}, 5$ $\mathrm{mm} / \mathrm{s}$ and axial force between 5 and $6 \mathrm{kN}$. The goal of this study was to optimize welding parameters for high tensile strength and low residual stress.

\section{KEY WORDS}

$\sim$ Optimum welding parameters

$\sim$ Tensile strength

$\sim$ Residual stress

$\sim$ Aluminum pipe

$\sim$ Butt joint

Universiti Kuala Lumpur Malaysian Institute of Marine Engineering Technology, Malaysia

e-mail: azman@unikl.edu.my

doi: 10.7225/toms.v10.n02.011

This work is licensed under (cc) BY

Received on: 28.06.2021/Revised on: 25.09.2021/Accepted on: 30.09.2021/Published: 21.10.2021

\section{INTRODUCTION}

Friction stir welding (FSW) can be used to cater for various sectors, such as aerospace, shipbuilding, automobile, marine and petro-chemical industries (Kohak \& Navthar, 2017). FSW is used in flat panel and pipe joining facilities. FSW is used to join two pieces together in a single run, soundly and without melting. During the FSW process, the material is plasticized by the stirring action of a high rotating tool and the joint is created through the plastic deformation of the material. This high rotating tool moves along the length of the weld, allowing the two pipes to be joined. The tool can rotate in two opposite directions, which are called the Advancing Side (AS), and the Retreading Side (RS). Tool rotation and weld directions are identical. This solid-state joining process is specifically used to weld the pieces that cannot be welded in the conventional way. There are many different types of FSW machines, including robots developed to cater to this purpose. However, FSW can still be performed by a normal CNC milling machine when welding small pieces. FSW joints have special characteristics, can have improved mechanical properties and be free from weld defects. The most significant process parameters that affect joint characteristics can be easily understood by studying the physical process in an experimental setting using the Taguchi method (Prasad \& Namala, 2017). They may include very low distortion, no fume production, no filler metals, no special surface treatment and no shielding gas (Verma \& Misra, 2017). During the FSW process, the stirred materials grow soft before reaching their melting point. Weld quality is dependent upon certain major welding parameters (Elanchezhian et al., 2014). Tool rotation speed, welding speed and axial force are critical, particularly when it comes to adjusting welding temperature to 
obtain better joining results. However, reverse conditions, such as low welding temperature, may create an insufficiently stirred interface, decrease tensile strength and increase residual stress. The low heat input in this welding technique helps avoid the degradation of the material and maintain high strength. The process can be carried out using a single pass method regardless of the thickness of the specimen involved (Senthil et al, 2020). The basic principle of the FSW process is shown in Figure 1 (Verma \& Misra, 2017). The main objective of this research is to determine the parameters that have the greatest effect on experimental output and predict the optimum combination of welding parameters that would yield the best mechanical properties with the highest tensile strength and lowest residual stress of friction stir welded pipe butt joints. Taking the research a step further, the Taguchi method was applied that uses an orthogonal array to determine the effect of parameters on quality outputs in a minimal number of experimental trials and obtain reliable results. The use of Taguchi's dynamic experiment approach to develop a robust process design with multiple quality outputs was justifiable (Siva Rama Krishna, 2016).

\section{MATERIALS AND METHOD}

The materials studied were AA6063 pipe structures. This aluminum pipe has the outside diameter of $89 \mathrm{~mm}$, the length of $100 \mathrm{~mm}$ and wall thickness of $5 \mathrm{~mm}$. The pipe joining setup for this experiment is shown in Figure 2. A configuration different than in the flat panel setup was used. Therefore, a customized jig was required. A cylindrically-shaped pin tool was used in the experimental setting, with the tool offset from the centerline by

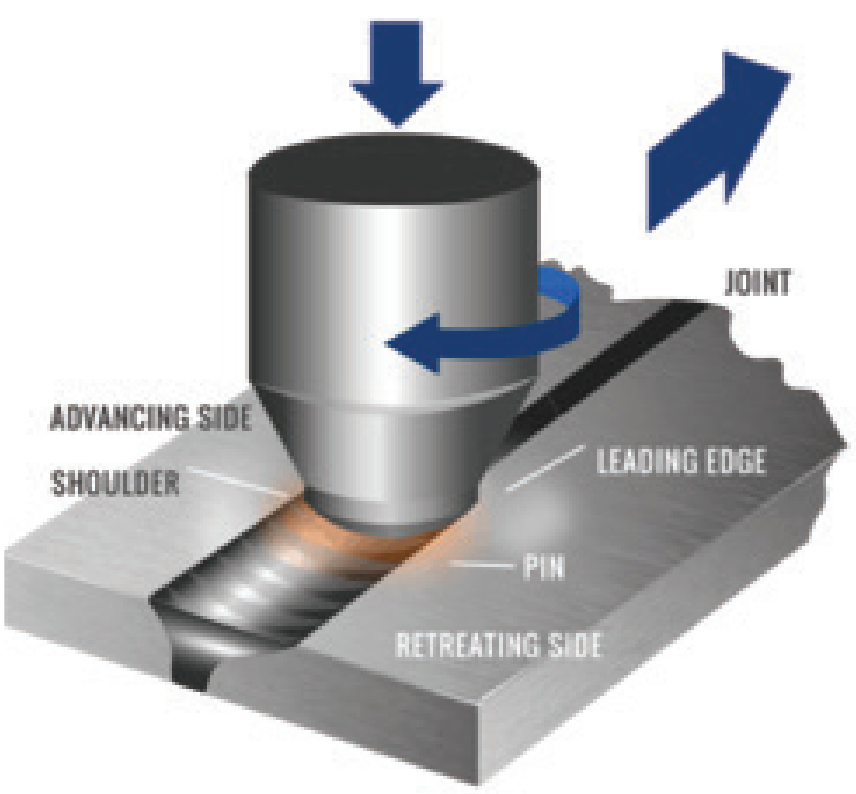

Figure 1.

The basic principle of the FSW process.

approx. $6 \mathrm{~mm}$ (Lammlein et al, 2011). The pipe was joined by FSW with various welding parameters as shown in Table 1. The welding parameters used in this study were tool rotation speed, travel speed, and axial force. Dwell time and plunge depth were set at $25 \mathrm{~s}$ and $4 \mathrm{~mm}$, respectively, for all pipe specimens.

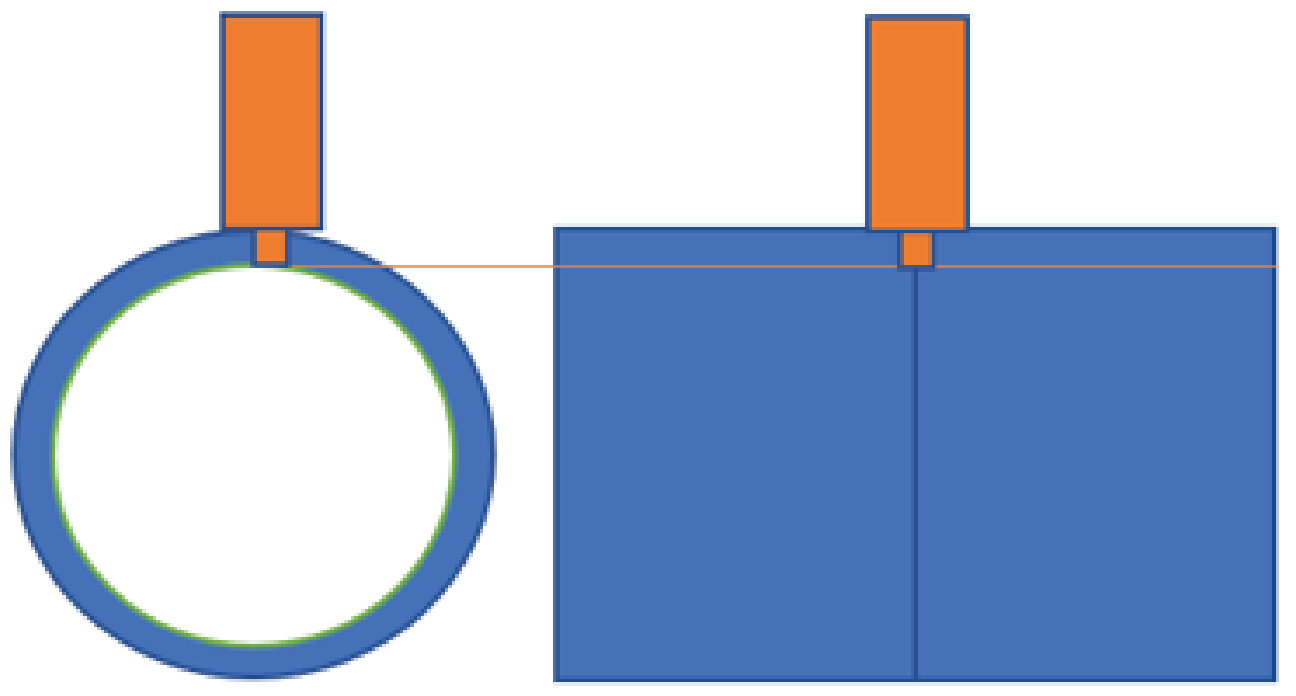

Figure 2.

Butt joint configuration for pipe joining. 
Table 1.

Welding parameters.

\begin{tabular}{lllll} 
Symbol & Parameter & Level 1 & Level 2 & Level 3 \\
\hline $\mathrm{N}$ & Tool rotation (RPM) & 1000 & 1300 & 1600 \\
\hline $\mathrm{S}$ & Travel speed $(\mathrm{mm} / \mathrm{s})$ & 3 & 4 & 5 \\
\hline $\mathrm{F}$ & Axial force $(\mathrm{kN})$ & 5 & 6 & 7 \\
\hline
\end{tabular}

A cylindrical tool made from $\mathrm{H} 13$ high carbon steel, with the shoulder diameter of $25 \mathrm{~mm}$, pin diameter of $5 \mathrm{~mm}$ and pin length of $4 \mathrm{~mm}$ was used. The tool schematic is shown in Figure 3 , and the arrangement of the equipment and pipe specimen in Figure 4.

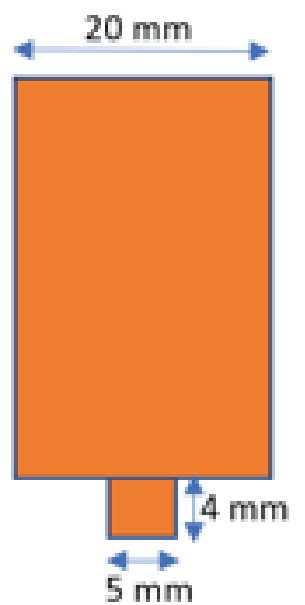

Figure 3.

FSW tool schematic.

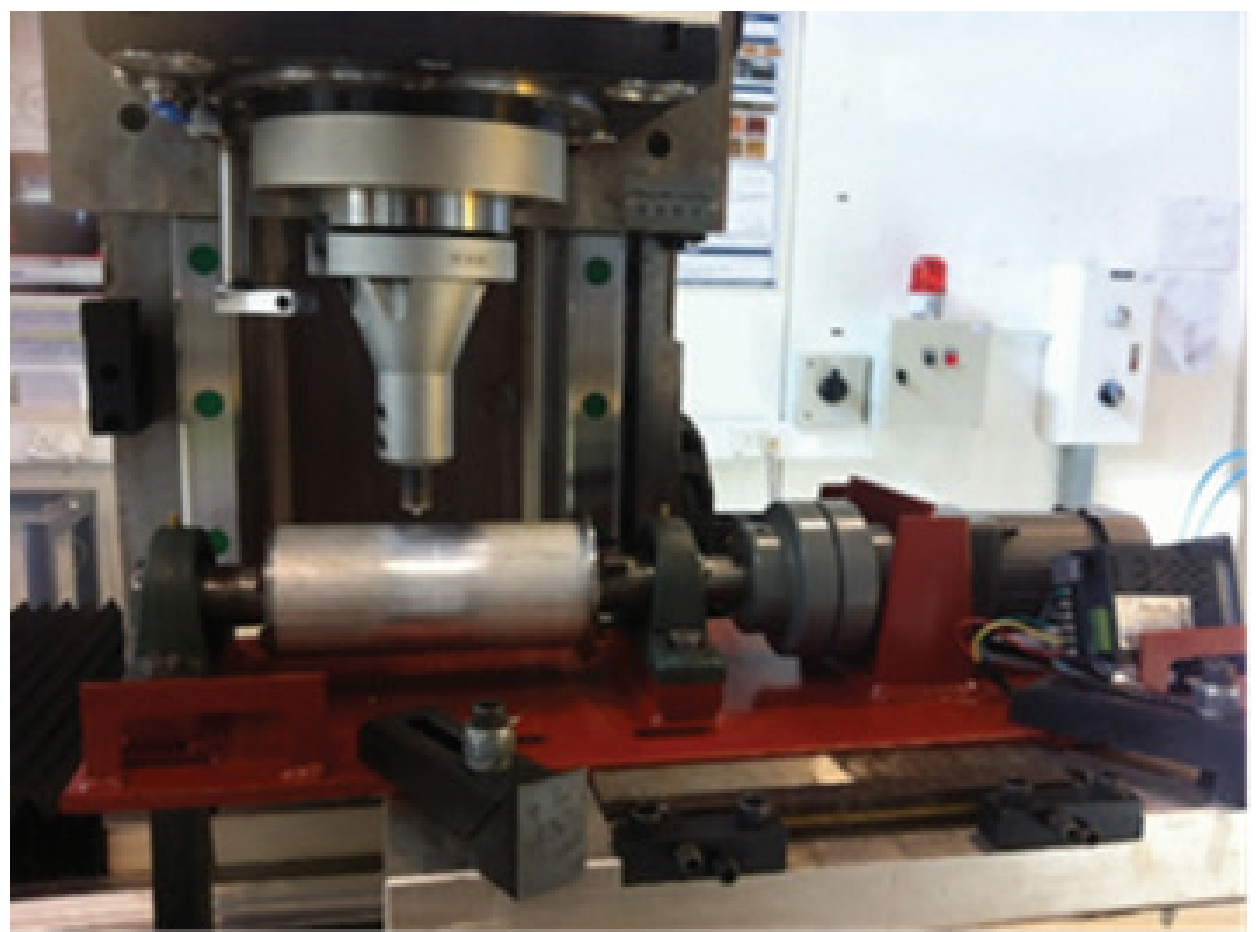

Figure 4

Experimental setup.

Taguchi devised a new method for developing experiments based on well-defined guidelines to reduce the number of experiments and obtain reliable outputs based on a proven concept (Dhanesh et al, 2021). The method uses a special set of arrays called orthogonal arrays. These standard arrays help pinpoint the manner in which to conduct the minimum number of experiments capable of providing complete information on all factors that affect performance parameters. Therefore, Taguchi L9 orthogonal array was used to reduce the number of experiments and still obtain reliable results. Nine experimental runs were conducted using the Taguchi L9 orthogonal array, as shown in Table 2. All nine good friction stir welded pipe specimens have been successfully prepared, with the joining process output sample shown in Figure 5. 
Table 2.

L-9 orthogonal array model.

\begin{tabular}{llll}
$\begin{array}{l}\text { Specimen No. } \\
\text { (S. No.) }\end{array}$ & $\begin{array}{l}\text { Rotational } \\
\text { Speed, } \mathrm{N} \\
(\mathrm{RPM})\end{array}$ & $\begin{array}{l}\text { Travel Speed, } \\
\mathrm{S}(\mathrm{mm} / \mathrm{s})\end{array}$ & $\begin{array}{l}\text { Axial Force, F } \\
(\mathrm{kN})\end{array}$ \\
\hline 1 & 1000 & 3 & 5 \\
\hline 2 & 1000 & 4 & 6 \\
\hline 3 & 1000 & 5 & 7 \\
\hline 4 & 1300 & 3 & 6 \\
\hline 5 & 1300 & 4 & 7 \\
\hline 6 & 1300 & 5 & 5 \\
\hline 7 & 1600 & 3 & 7 \\
\hline 8 & 1600 & 4 & 6 \\
\hline 9 & 1600 & 5 & 5 \\
\hline
\end{tabular}

In this study, the analysis of variance (ANOVA) was used to determine the effect of significant parameters on the performance of friction stir welded AA6063 pipe specimen (Siva Rama Krishna R, 2016). Tensile strength and residual stress of the friction stir welded pipe specimen were response variables. Rotation speed, travel speed and axial force were selected as control variables. The experiments were based on the rank order obtained through the Taguchi method, and the results using the 50 kN Universal Testing Machine Amsler HA50 for tensile strength and PANalytical EMPYREAN Multi-function X-Ray Diffractometer (XRD) for residual stress. Experimental data were analysed in Minitab 19.

This analysis was evaluated for a $95 \%$ confidence level, with the significance level a equal to 0.05 (Pradeep et al, 2013). Experimental results were transformed into a Signal to Noise $(\mathrm{S} / \mathrm{N})$ ratio. The $\mathrm{S} / \mathrm{N}$ ratio was defined as the ratio of the mean

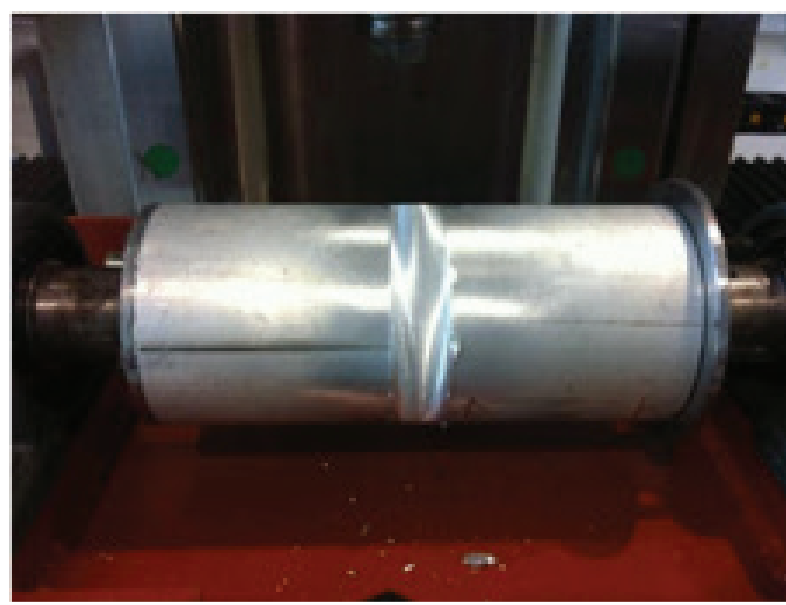

Figure 5.

Friction stir welded pipe joint.

of the signal and the standard deviation of the noise. The $\mathrm{S} / \mathrm{N}$ ratio indicates the degree of the predictable performance of a process in the presence of noise factors. The $\mathrm{S} / \mathrm{N}$ ratio was calculated using "the bigger the better" method to determine the optimum tensile strength and "the smaller the better" method to determine the optimum residual stress. The control parameter with the strongest influence was identified using the difference between the maximum and minimum values of the mean of $\mathrm{S} / \mathrm{N}$ ratios. The greater the difference between the mean of $\mathrm{S} / \mathrm{N}$ ratios, the greater the influence of the control parameter.

\section{RESULTS AND DISCUSSION}

The tensile strength average for each pipe joint specimen and residual stress at the midpoint of each pipe joint specimen are shown in Table 3.

Table 3.

The experimental results.

\begin{tabular}{llllll} 
S.No. & N (RPM) & $S(\mathrm{~mm} / \mathrm{s})$ & $\mathrm{F}(\mathrm{kN})$ & Tensile (MPa) & $\begin{array}{l}\text { Residual stress } \\
(\mathrm{MPa})\end{array}$ \\
\hline 1 & 1000 & 3 & 5 & 158.66 & -0.287 \\
\hline 2 & 1000 & 4 & 6 & 162.14 & -0.413 \\
\hline 3 & 1000 & 5 & 7 & 166.47 & -0.376 \\
\hline 4 & 1300 & 3 & 6 & 158.14 & -0.214 \\
\hline 5 & 1300 & 4 & 7 & 163.65 & -0.381 \\
\hline 6 & 1300 & 5 & 5 & -0.235 \\
\hline
\end{tabular}




\begin{tabular}{lllllll}
\hline 7 & 1600 & 3 & 7 & 160.91 & -0.622 \\
\hline 8 & 1600 & 4 & 6 & 162.87 & -0.303 \\
\hline 9 & 1600 & 5 & 5 & 161.69 & -0.193 & \\
\hline
\end{tabular}

\subsection{Tensile Strength}

Tensile strength is the maximum strength that a material can withstand without breaking when exposed to external loads. The highest tensile strength is indicative of a material's good mechanical properties (Arora et al, 2019). Therefore, the bigger, the better method was used to calculate the $\mathrm{S} / \mathrm{N}$ ratio and obtain optimum welding parameters for better tensile strength. The calculated values of tensile strength $\mathrm{S} / \mathrm{N}$ ratios are shown in Table 4.
Analysis of Variance (ANOVA) is a statistical method used to discuss the relative importance of the overall control factor. It can also be used to identify the contribution of each parameter. The F-test proposed by Fisher was used as an auxiliary tool of inspection (Verma, 2019). Thus, the higher the F-test value, the more dominant the parameters (Singarapu et al., 2015). Table 5 shows the ANOVA table of pipe joint specimen tensile strength.

Table 4.

Tensile strength $\mathrm{S} / \mathrm{N}$ ratio.

\begin{tabular}{llllll} 
S.No. & $\mathrm{N}(\mathrm{RPM})$ & $\mathrm{S}(\mathrm{mm} / \mathrm{s})$ & $\mathrm{F}(\mathrm{kN})$ & Tensile $(\mathrm{MPa})$ & $\mathrm{S} / \mathrm{N}$ ratio \\
\hline 1 & 1000 & 3 & 5 & 158.66 & 44.0096 \\
\hline 2 & 1000 & 4 & 6 & 162.14 & 44.1976 \\
\hline 3 & 1000 & 5 & 7 & 166.47 & 44.4265 \\
\hline 4 & 1300 & 3 & 6 & 158.14 & 43.9806 \\
\hline 5 & 1300 & 4 & 7 & 163.65 & 44.2782 \\
\hline 6 & 1300 & 5 & 5 & 170.52 & 44.6356 \\
\hline 7 & 1600 & 3 & 160.91 & 44.1314 \\
\hline 8 & 1600 & 4 & 6 & 162.87 & 44.2369 \\
\hline 9 & 1600 & 5 & 5 & 161.69 & 44.1739
\end{tabular}

Table 5.

ANOVA tensile strength table

\begin{tabular}{llllllll} 
Factor & DoF (f) & $\begin{array}{l}\text { Sum of } \\
\text { Square (SS) }\end{array}$ & $\begin{array}{l}\text { Mean of } \\
\text { squares }\end{array}$ & F-value & P-value & Variance (V) & \% \\
\hline $\mathrm{N}$ & 2 & 8.367 & 4.183 & 0.536346 & 0.650915 & 0.268173 & 7.10 \\
\hline $\mathrm{S}$ & 2 & 73.38 & 36.691 & 4.703846 & 0.175322 & 2.351923 & 62.24 \\
\hline $\mathrm{F}$ & 2 & 20.55 & 10.27 & 1.317308 & 0.431537 & 0.658654 & 17.43 \\
\hline Error & 2 & 15.6 & 7.8 & & & 13.23 \\
\hline Total & 8 & 117.897 & & & & 100.00 \\
\hline
\end{tabular}

Table 5 clearly shows that the combined effect of tool rotation speed and axial force is much lower than the effect of travel speed that was proven to be major $-62.24 \%$. The detailed percentages of the effect of the $\mathrm{S} / \mathrm{N}$ ratio of each parameter are indicated in Table 6. Similar travel speed, accounting for $62.75 \%$, was identified as the main factor affecting tensile strength.

Optimum welding parameters can be identified using the response table shown in Table 7, while the main effect plot can be seen in Figure 6. 
Table 6.

Effect of tensile strength $\mathrm{S} / \mathrm{N}$ ratio in percentages.

\begin{tabular}{|c|c|c|c|c|c|c|c|}
\hline \multirow[t]{2}{*}{ Factor } & \multirow[t]{2}{*}{ DoF } & \multicolumn{3}{|c|}{ Average S/N } & \multirow{2}{*}{$\begin{array}{l}\text { Sum of } \\
\text { squares }\end{array}$} & \multirow[t]{2}{*}{ Mean square } & \multirow[t]{2}{*}{$\%$} \\
\hline & & L1 & L2 & L3 & & & \\
\hline $\mathrm{N}$ & 2 & 44.2112 & 44.2981 & 44.1807 & 0.02226 & 0.01113 & 6.74 \\
\hline$S$ & 2 & 44.0405 & 44.2376 & 44.4120 & 0.2072 & 0.10362 & 62.75 \\
\hline $\mathrm{F}$ & 2 & 44.2940 & 44.1174 & 44.2787 & 0.05749 & 0.02874 & 17.41 \\
\hline Error & 2 & & & & 0.04324 & 0.02162 & 13.10 \\
\hline Total & 8 & & & & 0.33019 & & 100.00 \\
\hline
\end{tabular}

\section{Table 7.}

Tensile strength response table (Control factor: the bigger, the better).

\begin{tabular}{llll} 
Level & Rotational speed, $N$ & Travel speed, $S$ & Axial Force, $\mathrm{F}$ \\
\hline 1 & 44.21 & 44.04 & 44.29 \\
\hline 2 & 44.30 & 44.24 & 44.12 \\
\hline 3 & 44.18 & 44.41 & 44.28 \\
\hline Delta & 0.12 & 0.37 & 0.18 \\
\hline Rank & 3 & 1 & 2 \\
\hline
\end{tabular}

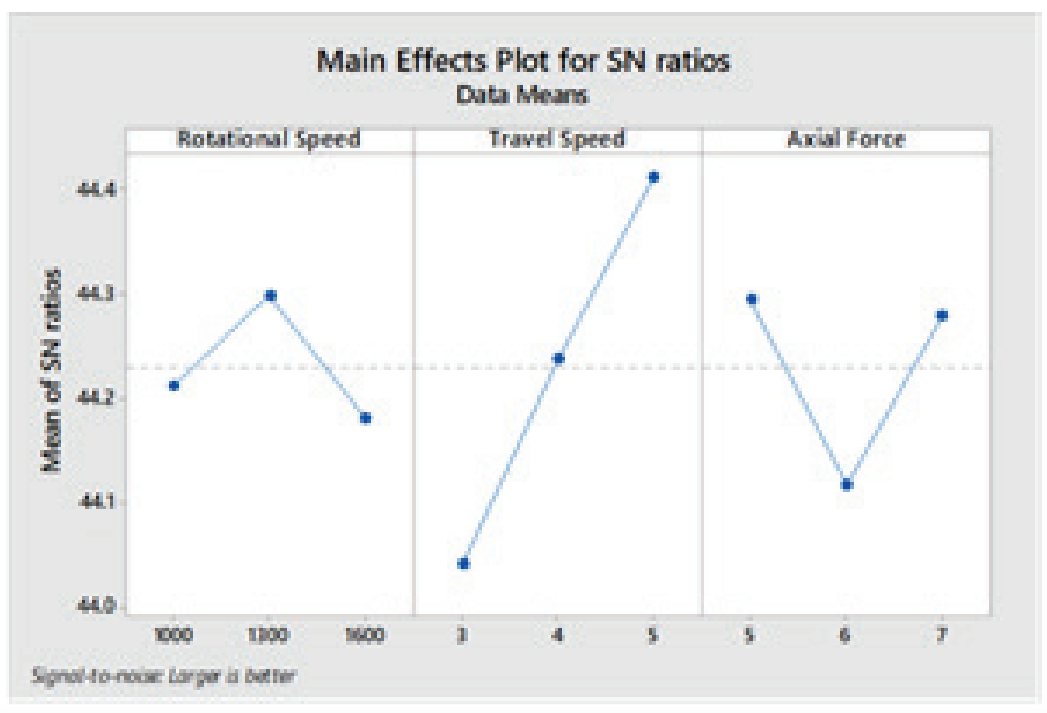

Figure 6.

Main effect plot for tensile strength $\mathrm{S} / \mathrm{N}$ ratio. 
Table 7 and Figure 6 show that the optimum welding conditions for high tensile strength are tool rotation speed of $1300 \mathrm{rpm}$, travel speed of $5 \mathrm{~mm} / \mathrm{s}$ and axial force of $5 \mathrm{kN}$. These optimum parameters can be summarized as in Table 8 .

Table 8.

Optimum parameters and levels (based on the highest response).

\begin{tabular}{lll} 
Factors & Level description & Level \\
\hline Rotational speed, N & 1300 & 2 \\
\hline Travel speed, S & 5 & 3 \\
\hline Axial force, F & 5 & 1 \\
\hline
\end{tabular}

\subsection{Residual Stress}

Residual stress is the stress remaining in a body after all applied stresses have been removed (Xu et al, 2014). In combination with applied stress, it can cause failure at an unusually low level (Rajakumar et al., 2011). Therefore, residual stress must be kept as low as possible to prevent premature failure and maintain structural integrity. The smaller, the better method was used to calculate the residual stress $\mathrm{S} / \mathrm{N}$ ratio. Then, the value of the residual stress $\mathrm{S} / \mathrm{N}$ ratio was calculated and is indicated in Table 9. In this study, the ANOVA was used to identify the effect of each parameter and the results are shown in Table 10.

Table 9.

Residual stress S/N ratio (Mode*: C- compression mode).

\begin{tabular}{|c|c|c|c|c|c|c|}
\hline S.No & $\begin{array}{l}\text { Rotation speed, } \\
\text { N (RPM) }\end{array}$ & $\begin{array}{l}\text { Travel speed, S } \\
(\mathrm{mm} / \mathrm{s})\end{array}$ & $\begin{array}{l}\text { Axial force, F } \\
(k N)\end{array}$ & $\begin{array}{l}\text { Residual stress } \\
(\mathrm{MPa})\end{array}$ & Mode* & $\mathrm{S} / \mathrm{N}$ ratio $(\mathrm{dB})$ \\
\hline 1 & 1000 & 3 & 5 & 0.287 & C & 10.8301 \\
\hline 2 & 1000 & 4 & 6 & 0.413 & C & 7.6848 \\
\hline 3 & 1000 & 5 & 7 & 0.376 & C & 8.4907 \\
\hline 4 & 1300 & 3 & 6 & 0.214 & C & 13.3817 \\
\hline 5 & 1300 & 4 & 7 & 0.381 & $C$ & 8.3709 \\
\hline 6 & 1300 & 5 & 5 & 0.235 & C & 12.5731 \\
\hline 7 & 1600 & 3 & 7 & 0.622 & $C$ & 4.1264 \\
\hline 8 & 1600 & 4 & 5 & 0.303 & C & 10.3688 \\
\hline 9 & 1600 & 5 & 6 & 0.193 & $C$ & 14.2733 \\
\hline
\end{tabular}

Table 10.

ANOVA table for residual stress.

\begin{tabular}{llllllll} 
Factor & DoF $(\mathrm{f})$ & $\begin{array}{l}\text { Sum of square } \\
(\mathrm{SS})\end{array}$ & $\begin{array}{l}\text { Mean of } \\
\text { squares }\end{array}$ & F-value & P-value & Variance (V) & \% \\
\hline $\mathrm{N}$ & 2 & 0.01607 & 0.008037 & 0.468513 & 0.680967 & 0.008035 & 11.47 \\
\hline $\mathrm{S}$ & 2 & 0.02088 & 0.01044 & 0.608746 & 0.62162 & 0.00522 & 14.91 \\
\hline $\mathrm{F}$ & 2 & 0.06883 & 0.03442 & 2.0067 & 0.332591 & 0.0034415 & 49.14 \\
\hline Error & 2 & 0.0343 & 0.01715 & & & 24.49 \\
\hline Total & 8 & 0.14008 & & & & 100.00 \\
\hline
\end{tabular}


Table 10 shows that the combined effect of tool rotation speed and welding speed is much lower than the effect of axial force (Singarapu et al., 2015). Axial force has a major effect - $49.14 \%$. The percentage of $\mathrm{S} / \mathrm{N}$ ratio contribution for each parameter can be seen in Table 11, which also confirmed axial force as the main residual stress affecting factor with the share of $50.43 \%$.

The optimum welding parameters can be identified using the response table shown in Table 12 and the main effect plot depicted in Figure 7.

Table 11.

Percentage of $\mathrm{S} / \mathrm{N}$ ratio contribution of residual stress.

$\begin{array}{llll}\text { Factor DoF } & \text { Average } S / N & \text { Sum of } & \text { Mean square } \\ \text { squares }\end{array}$

\begin{tabular}{lllllllll}
\hline & & L1 & L2 & L3 & & & \\
\hline $\mathrm{N}$ & 2 & 9.0019 & 11.4419 & 9.5895 & 9.730 & 4.865 & 11.88 \\
\hline $\mathrm{S}$ & 2 & 9.4461 & 8.8082 & 11.7790 & 14.68 & 7.338 & 17.92 & 50.43 \\
\hline $\mathrm{F}$ & 2 & 11.2573 & 11.7799 & 6.9960 & 41.32 & 20.659 & 19.78 \\
\hline Error & 2 & & & & 16.203 & 8.1015 & 100.00 \\
\hline Total & 8 & & & & & & &
\end{tabular}

Table 12.

Response table for residual stress (Control factor: small is better).

\begin{tabular}{llll} 
Level & Rotation speed, $\mathrm{N}$ & Travel speed, $\mathrm{S}$ & Axial Force, $\mathrm{F}$ \\
\hline 1 & 9.002 & 9.446 & 11.257 \\
\hline 2 & $\mathbf{1 1 . 4 4 2}$ & 8.808 & $\mathbf{1 1 . 7 8 0}$ \\
\hline 3 & 9.589 & $\mathbf{1 1 . 7 7 9}$ & 6.996 \\
\hline Delta & 2.440 & 2.971 & 4.784 \\
\hline Rank & 3 & 2 & 1 \\
\hline
\end{tabular}

Table 12 and Figure 7 show that the optimum welding conditions for low residual stress are tool rotation speed of $1300 \mathrm{rpm}$, travel speed of $5 \mathrm{~mm} / \mathrm{s}$ and axial force of $6 \mathrm{kN}$. These optimum parameters can be summarized as in Table 13.
Table 13.

Optimum parameters and levels (based on the highest response).

\begin{tabular}{lll} 
Factors & Level description & Level \\
\hline Rotation speed, N & 1300 & 2 \\
\hline Travel speed, S & 5 & 3 \\
\hline Axial force, F & 6 & 2 \\
\hline
\end{tabular}




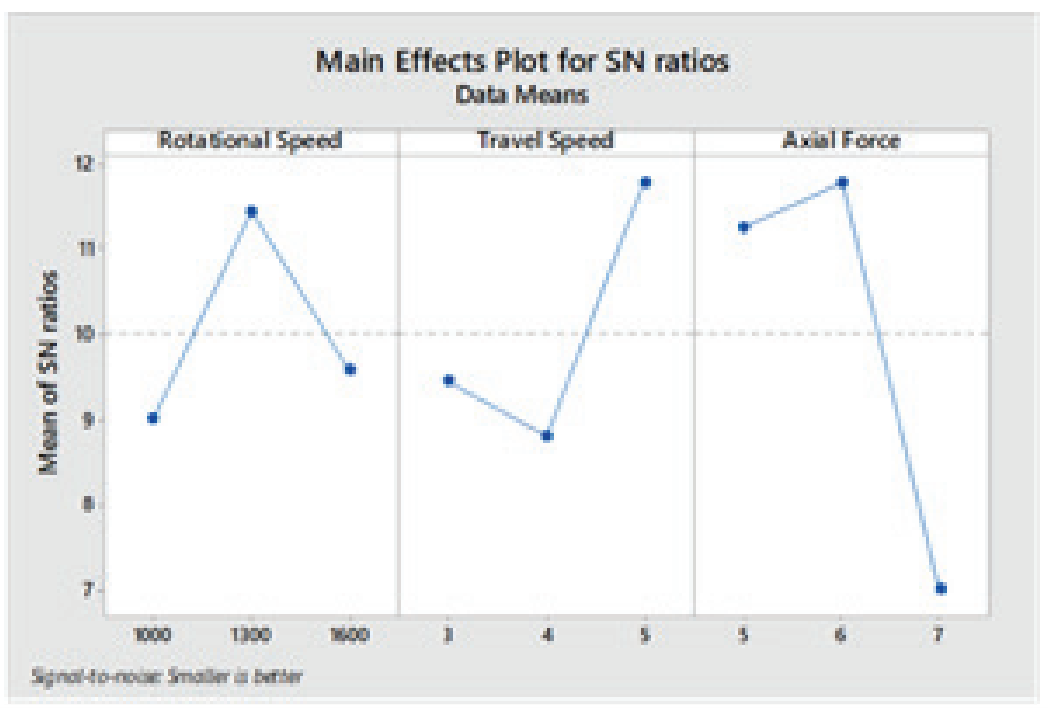

Figure 7.

Main effects plot for residual stress $\mathrm{S} / \mathrm{N}$ ratio.

\subsection{Microstructure Comparison}

In spite of the different inputs used, such as tensile strength and residual stress, the calculations yielded quite similar welding parameters of the rotation speed of $1300 \mathrm{rpm}$, travel speed of $5 \mathrm{~mm} / \mathrm{s}$ and axial force of 5-6 kN. The microstructure for this parameter is shown in Figure 8 (Ismail et al, 2020).

In Figure 8, microstructural images show uniform grain structure across the zones regardless of their size, with a finer grain structure in the WNZ. According to the Hall-Petch equation, the yield strength of the alloy increases with the decrease in grain size (Li, Bushby and Dunstan, 2016). Grain sizes were smaller than that of the base metal. That was the reason why the majority of the fractures occurred in the base metal region during the tensile test. Finer grain structure generated low residual stress in the friction stir welded zone (Ismail et al., 2021). Grain refinement can be attributed to the sufficient amount of friction heat generated under the selected welding parameters. These grain structures improved mechanical properties and residual stress characteristics confirmed by the findings.

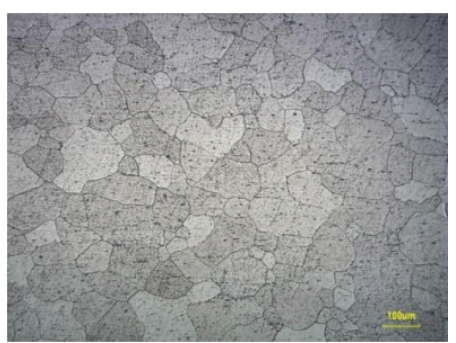

a)

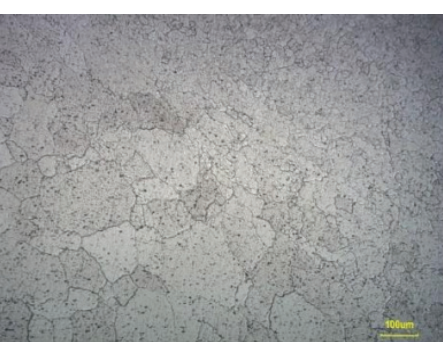

b)

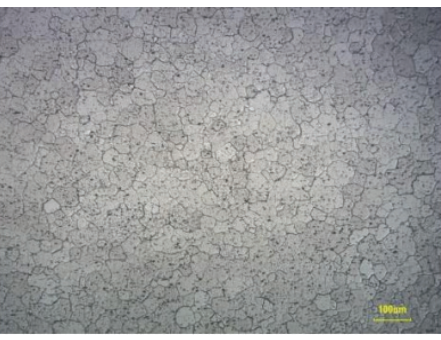

c)

Figure 8.

Microstructural evolution under the stated welding parameters ( a) Heat affected zone (HAZ), b) Thermo-mechanically affected zone (TMAZ), c) Weld nugget zone (WNZ). 


\section{CONCLUSION}

The Taguchi method was successfully utilized to identify the optimum welding parameters for friction stir welded AA6063 pipe butt joints. Based on different tensile strength and residual stress inputs, the optimum welding parameters were found to be the rotation speed of $1300 \mathrm{rpm}$, travel speed of $5 \mathrm{~mm} / \mathrm{s}$ and axial force of 5-6 kN. Factors with the greatest effect on tensile strength and residual stress are travel speed and axial force, respectively. These two parameters need to be closely monitored when friction stir welding pipe butt joints.

\section{ACKNOWLEDGEMENT}

The Short-Term Research Grant (STR20012) provided by the Universiti Kuala Lumpur was greatly appreciated.

\section{REFERENCES}

Dhanesh, G. M. and Gopi, S., 2021. Optimized Parameters Prediction for Single-Pass Friction Stir Welding on Dissimilar Aluminium Alloys T- Joint, International Journal on Emerging Technologies, 12(2), pp. 22-27.

Elanchezhian, C. et al., 2014. Parameter Optimization of Friction Stir Welding Of AA8011-6062 Using Mathematical Method. Procedia Engineering, 97, pp.775-782. Available at:

http://dx.doi.org/10.1016/j.proeng.2014.12.308.

Arora, H., Singh, R. \& Brar, G.S., 2019. Thermal and structural modelling of arc welding processes: A literature review. Measurement and Control, 52(7-8), pp.955969. Available at:

http://dx.doi.org/10.1177/0020294019857747.

Ismail, A. et al., 2019. The Effects of Welding Parameters on Macro and MicroStructure of Friction Stir Welded Aluminium. IOP Conference Series: Materials Science and Engineering, 536(1), p.012014. Available at: http://dx.doi.org/10.1088/1757-899x/536/1/012014.

Ismail, A. et al., 2021. Residual stress analysis of friction stir welded AA6063 pipe butt joint by neutron diffraction technique of ENGIN-X. IOP Conference Series: Materials Science and Engineering, 1045(1), p.012007. Available at: http://dx.doi.org/10.1088/1757-899x/1045/1/012007.

Xu, J. et al., 2014. Residual Stress Analyses in a Pipe Welding Simulation: 3D Pipe Versus Axi-symmetric Models. Procedia Materials Science, 3, pp.511-516. Available at: http://dx.doi.org/10.1016/j.mspro.2014.06.085.

Lammlein, D.H. et al., 2011. The friction stir welding of small-diameter pipe: an experimental and numerical proof of concept for automation and manufacturing.
Proceedings of the Institution of Mechanical Engineers, Part B: Journal of Engineering Manufacture, 226(3), pp.383-398. Available at: http://dx.doi.org/10.1177/0954405411402767.

Li, Y., Bushby, A.J. \& Dunstan, D.J., 2016. The Hall-Petch effect as a manifestation of the general size effect. Proceedings of the Royal Society A: Mathematical, Physical and Engineering Sciences, 472(2190), p.20150890. Available at: http://dx.doi.org/10.1098/rspa.2015.0890.

Pradeep, A. \& Muthukumaran, S., 2018. An analysis to optimize the process parameters of friction stir welded low alloy steel plates. International Journal of Engineering, Science and Technology, 5(3), pp.25-35. Available at: http://dx.doi.org/10.4314/ijest.v5i3.3.

Prasad, M.V.R.D. \& kumar Namala, K., 2018. Process Parameters Optimization in Friction Stir Welding by ANOVA. Materials Today: Proceedings, 5(2), pp.4824-4831. Available at: http://dx.doi.org/10.1016/j.matpr.2017.12.057.

Praveen, G. K., \& Navthar, R. R., 2017. Optimization of Process parameters of Friction Stir Welding for Similar HE-30 Aluminium Alloy. International Research Journal of Engineering and Technology (IRJET), 4(7), pp.1040-1048. Available at: https://irjet. net/archives/V4/i7/IRJET-V4I7238.pdf.

Rajakumar, S., Muralidharan, C. \& Balasubramanian, V., 2011. Statistical analysis to predict grain size and hardness of the weld nugget of friction-stir-welded AA6061-T6 aluminium alloy joints. The International Journal of Advanced Manufacturing Technology, 57(1-4), pp.151-165. Available at: http://dx.doi.org/10.1007/s00170-011-3279-5.

Singarapu, U., Adepu, K. \& Arumalle, S.R., 2015. Influence of tool material and rotational speed on mechanical properties of friction stir welded AZ31B magnesium alloy. Journal of Magnesium and Alloys, 3(4), pp.335-344. Available at: http://dx.doi.org/10.1016/j.jma.2015.10.001.

Siva Rama Krishna, P. K. T., 2016. Optimization of Process Parameters of Friction Stirs Welding of Aluminum Alloys (6061) Using Taguchi Method. International Journal of Science and Research (IJSR), 5(3), pp.1988-1994. Available at: http://dx.doi.org/10.21275/v5i3.nov162391

Senthil, S.M. et al., 2020. A multi-objective optimization of the friction stir welding process using RSM-based-desirability function approach for joining aluminum alloy 6063-T6 pipes. Structural and Multidisciplinary Optimization, 62(3), pp.1117-1133. Available at:

http://dx.doi.org/10.1007/s00158-020-02542-2.

Verma, S., Misra, J.P. \& Gupta, M., 2019. Study of Temperature Distribution and Parametric Optimization during FSW of AA6082 Using Statistical Approaches. SAE International Journal of Materials and Manufacturing, 12(1), pp.73-82. Available at: http://dx.doi.org/10.4271/05-12-01-0005.

Verma, S. \& Misra, J.P., 2015. A Critical Review of Friction Stir Welding Process. DAAAM International Scientific Book, pp.249-266. Available at: http://dx.doi.org/10.2507/daaam.scibook.2015.22. 